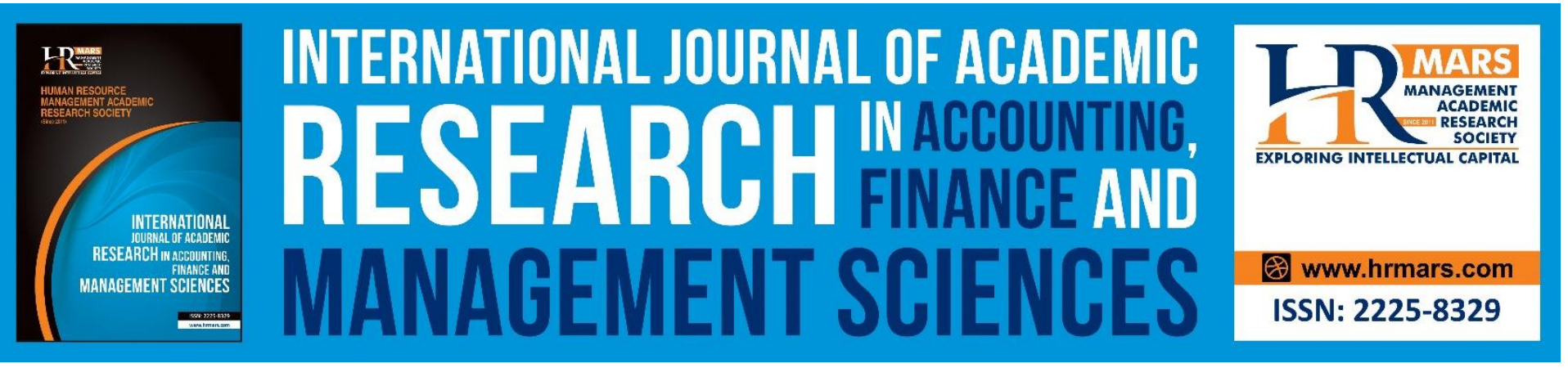

\title{
The Digital Evolution of Consumer Purchasing Methods and the Impact on Retail
}

\section{Giuseppe Granata}

To Link this Article: http://dx.doi.org/10.6007/IJARAFMS/v10-i4/8429

DOI:10.6007/IJARAFMS /v10-i4/8429

Received: 10 November 2020, Revised: 11 December 2020, Accepted: 26 December 2020

Published Online: 15 January 2021

In-Text Citation: (Granata, 2021)

To Cite this Article: Granata, G. (2021). The Digital Evolution of Consumer Purchasing Methods and the Impact on Retail. International Journal of Academic Research in Accounting, Finance and Management Sciences, 4(1), 1-7.

Copyright: (C) 2021 The Author(s)

Published by Human Resource Management Academic Research Society (www.hrmars.com)

This article is published under the Creative Commons Attribution (CC BY 4.0) license. Anyone may reproduce, distribute, translate and create derivative works of this article (for both commercial and non-commercial purposes), subject to full attribution to the original publication and authors. The full terms of this license may be seen at: $\underline{\text { http://creativecommons.org/licences/by/4.0/legalcode }}$

Vol. 10, No. 4, 2021, Pg. 1 - 7

http://hrmars.com/index.php/pages/detail/IJARAFMS

JOURNAL HOMEPAGE

Full Terms \& Conditions of access and use can be found at http://hrmars.com/index.php/pages/detail/publication-ethics 


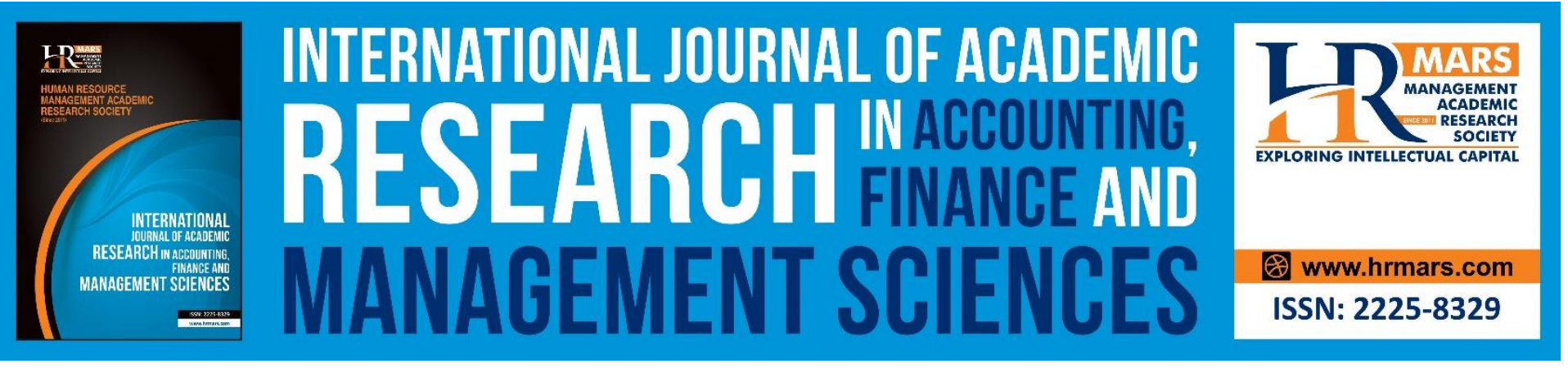

\title{
The Digital Evolution of Consumer Purchasing Methods and the Impact on Retail
}

\author{
Giuseppe Granata \\ Departement of Economics, University Mercatorum - Rome, Italy. \\ Giuseppe Granata, Department of Economics, University Mercatorum - Rome, Italy. \\ Email: giuseppe.granata@unimercatorum.it
}

\begin{abstract}
The distribution channels are on the stage of radical change. The success of the online channel and digitalization driven by a few leading companies in recent years has dramatically changed the way people live and change purchasing patterns. New technologies have multiplied touchpoints, broadband connection has increased the number of always-on consumers and, at the same time, has developed online shopping (Pentina \& Hasty, 2009).

What are the implications of digital technological innovations? Will the physical store continue to play a key role? Will online shopping be able to offer an engaging and exciting consumer experience? New ways of selling and exhibiting products are emerging, as well as new ways of buying, such as the use of physical and online channels, and other ways, such as showrooming. It consists in obtaining information about a product at the point of sale, receiving all useful information and finally, buying it online. This practice is often adopted to save money, because it is known that online prices are lower than in retail stores, but it also arises from the customer's need to touch the products firsthand before buying them. More and more retailers are experiencing this phenomenon that leads them to be a great showcase, provide information, let people touch products and eventually make fewer sales.

The integration of e-commerce with physical channels creates opportunities and synergies: companies can offer multiple services through different channels and for different target segments. Internet retail is creating greater customer value in terms of additional services and additional touchpoints.
\end{abstract}

Keywords: Showrooming, Omnichannel, Retail 4.0, Smartphone, Digital Communication.

\section{Introduction}

Nowadays, entrepreneurs have to develop new strategies such as multichannel ones in order to face the digital revolution. These strategies include the addition of new channels, using digital technologies, to better interact and engage consumers. (Verhoef, Neslin \& Vroomen, 2007). In this new competitive scenario, entrepreneurs begin to evaluate and manage the experiences of their customers through the techniques of relationship marketing in order to establish and improve 
INTERNATIONAL JOURNAL OF ACADEMIC RESEARCH IN ACCOUNTING, FINANCE AND MANAGEMENT SCIENCES

Vol. 10, No. 4, 2021, E-ISSN: 2225-8329 ๑ 2021 HRMARS

relationships with customers. Moreover, thanks to digital and social media, for example, they can integrate all the retailing-mix levers, involving the various distribution channels (Neslin et al., 2006). Thus, we have been assisting for several years now the various distributors who are transforming sales strategies into multichannel marketing. On the other hand, those who are more active, more inclined and open to digitalization, have turned to online, offline and omnichannel integration (Rigby, 2011), with the aim of increasingly involving consumers by means of various initiatives, promotions and actions in order to always have a constant exchange of information and relationships with their customers. Currently, this new omnichannel retail system is limited for a few grounds that we will try to explore. This limitation is accentuated when we refer to retailers, especially small ones.

\section{Theoretical and Review of Literature}

Research in the distribution sector has always addressed these issues by making a clear distinction between the various channels. This is because even in practice, distributors were positive about keeping the physical channel and the online channel separate. Only later, these new methods of a distribution, multichannel and omnichannel, were studied in literature and research because of the integration of channels (Verhoef, Kannan \& Inman, 2015).

More frequently today, there is a certain confusion between distribution and marketing channels, the consumer considers them as one thing, without any distinction. (Herhausen, Binder, Schoegel \& Herrmann, 2015).

This revolution in the field of distribution can also refer to other strategies or solutions designed and built for certain consumers to be used at any time and in any place (Fairchild, 2014). Thus, we will have more omnichannel consumers who simultaneously use many or all of the sales channels available for the purchasing process, this type of sale creates the concept of integration between all physical and digital channels (Rigby, 2011; Frazer \& Stiehler, 2014). With omnichannel, a synergistic management between the various channels is implemented to engage and optimize the consumer experience. However, it also happens that the terms 'omnichannel' and 'multichannel' are used as synonyms. Therefore, a great distinction was made in the reference literature by mentioning omnichannel retailing as a new distribution method. The literature considers the sale of goods and services as an activity that is carried out through the activation of all channels at the same time, by fully involving consumers through different digital media such as social media (Beck \& Rygl, 2015).

For about a decade, these phenomena have been studied in the literature, where several empirical analyses among distributors were also conducted (Brynjolfsson, Hu \& Rahman, 2013; Lewis, Foster \& Whysall, 2013; Strang, 2013). We started from the analysis of the phenomenon trying to understand what could be the challenges that distributors would have to face (Herhausen et al., 2015) and analyzing the various implications for all distributors along the supply chain (Brynjolfsson et al., 2013). In fact, various market rules and consumer habits have changed in the last ten years. Nowadays, the new omnichannel strategies are used in a more intelligent way through the use of digital technologies. In this revolution of the sector and the market, Desai, Potia and Salsberg (2012) have defined a new type of distribution called Retail 4.0. This new 4.0 type provides for integration of physical and digital sales, which create different purchasing methods, including mixed ones. For example, the consumer can buy a product online and collect it from the store and vice versa. The consumer can still buy and collect a product online but in case of defects or changing one's mind, he/she can return the product to the store. This new method defined as 4.0 offers customers different purchasing formulas and even more. For instance, the consumer can get information online, 
INTERNATIONAL JOURNAL OF ACADEMIC RESEARCH IN ACCOUNTING, FINANCE AND MANAGEMENT SCIENCES

Vol. 10, No. 4, 2021, E-ISSN: 2225-8329 ๑ 2021 HRMARS

draw comparisons and learn about the prices until booking a product and then, collect it in the physical store. Through different available forms such as smartphones, tablets, virtual fitting rooms, interactive mirrors, live chats, etc., consumers can receive information and proceed to the booking or direct purchase of a product. Thus, different distributors are starting to reduce the number of physical stores by focusing on the development of new virtual spaces in order to attract more consumers. Today, the challenges that distributors have to face with are related to the digitalization of sales. We refer not only to e-commerce but also to a strong presence on digital communication channels: from social networks to company's corporate website, from smartphone and tablet apps to digital communication actions.

An unexpected result is also recorded in the literature. Despite the increase in online sales, digital market presence, engagement and consumer relations actions, sales in physical stores continue to take place. This is due to the fact that physical stores will always remain the reference point for certain categories of consumers and consumers still want to have direct contact with sellers, touch and try products directly. In this situation, online sales favor purchases in stores and, thus, new phenomena of consumer behavior for purchasing arise, that we can define as showrooming and webrooming (Verhoef et al., 2007). The reasons that push consumers to make online purchases are because of its convenience and wider choice of online products. However, it is opposite for consumers who prefer making purchases in traditional stores: they do so because they want to touch a product before buying it, make sure of its quality and manufacture, etc. Moreover, they keep using this type of purchasing because they are afraid of receiving fake products or products with lower quality than it was promised in the online store. However, the research results confirm that, in order to increase in online sales, it is very important for retailers to adopt a sales system based on omnichannel, taking advantage of all the tools made available by digital technologies.

\section{The Showrooming Phenomenon}

In the digital age, there has not been a sharp decrease in offline sales to the advantage of online sales in the distribution sector. Consumers who are more oriented towards omnichannel, have not abandoned physical stores, trying to make assessments by choosing between online and offline. As seen above, technology has revolutionized consumer behavior. Nowadays, users are always connected and constantly receive push notifications from retailers or online distribution platforms. Smartphones, tablets, apps and social media in general have changed the way consumers approach shopping. In fact, they are people who have not a lot of free time to shop, to find information, but, above all, they prefer online purchasing because of larger assortment and easier way of searching for it in the stores (Piotrowicz \& Cuthbertson, 2014). As a matter of fact, the ability to use multiple online channels makes it easier to compare products between various distributors and compare various offers and promotions (Brynjolfsson et al., 2013; Strang, 2013). A few years ago, before the digitalization, the consumer trusted the information received from family and friends. Today consumers easily get information, reviews and comments from the Internet. Many consumers use the Internet to find the product but then buy it in a physical store. On the other hand, others try the products in the points of sale, because they want to see the quality, the beauty etc., but then they prefer the online purchase because of lower price. This phenomenon occurs in production sectors or in any other type of sector. Such sectors as fashion, electronics, and mechanics are suitable for this type of use of mixed distribution channels, online and offline (Granata \& Scot 2019). With the advent of the new millennium, doubts about digitalization and the web have given way to a digital 
INTERNATIONAL JOURNAL OF ACADEMIC RESEARCH IN ACCOUNTING, FINANCE AND MANAGEMENT SCIENCES

Vol. 10, No. 4, 2021, E-ISSN: 2225-8329 @ 2021 HRMARS

orientation. For example, fashion and luxury brands have started slowly approaching the online channel, adapting to traditional offline stores concept. The rapid growth of the Internet, smartphones and social media combined with the widespread connectivity of online users who wanted to actively participate in the buying process, has "forced" companies to invest in the digital marketing. For example, fashion brands have started focusing more on their web pages, conveying a clear image, and introducing innovative services, such as virtual mannequins and dressing rooms, online sellers, 3D technologies, e-commerce sites, social networks and mobile apps. Today, fashion retailers are starting to extend their digital presence through fashion apps and Facebook, Instagram and Pinterest pages where companies post photos and videos of new collections, fashion shows and backstage with the aim of creating a story and involving consumers in the world of brands (Granata \& Scot, 2018). However, in general, clients who choose between online and offline shopping still want to see, hear, touch and try a product and soak up the atmosphere of the store. In the fashion and luxury sector, for instance, the physical store will continue to play the primary role. The integration of physical and digital processes still remains a challenge. In any case, the physical store remains a fundamental point of contact. In the new context, it is essential for retailers to renew their concept stores by implementing innovative in-store technologies so that the physical point of sale can evolve from a logistics center to an experiential place. The challenge is precisely to build an omnichannel approach that does not affect the experience, to bring the consumers closer to the brand in a more sophisticated, engaging and complete way, offering them a "complete" customer experience.

In order to transform into the omnichannel form, companies can use various tools such as virtual fitting rooms. They are equipped with a video camera behind a mirror where a client can try the products virtually. Nowadays, various distribution companies have opened virtual stores on the network in addition to physical stores, adopting digital technologies. In order to be closer to consumers, to provide them with more information and offer a more personalized service. So as to make available a multitude of digital tools at the point of sale, to promote shopping, experience, personalization, fun and innovation (Moretta Tartaglione \& Granata, 2019).

\section{Results and Conclucions}

Technology, Internet and digital tools have enabled distributors to create more value for consumers in terms of information and additional services, also offering the possibility to make purchases in different ways, moving from a media scarcity condition to a condition of media pluralism (Sawhney \& Kotler, 2001). Omnichannel together with technology have allowed entrepreneurs to better organize their sales by integrating the various channels. It has led to cost reduction, an increase in information, and the collection of a large amount of data, that are very useful for the company. In addition, the power of mobile, the growing penetration of mobile devices and the consequent dependence on smartphones have significantly changed consumer behavior, their decision-making, and the way they live and work in general.

Many retailers have understood the importance of the online channel and smartphone apps. According to the omnichannel approach, retailers started using this channel to better satisfy consumers and to be closer to them. The new challenges that distributors face are to create an interesting and significant customer experience. This race to integrate channels brings benefits for entrepreneurs and consumers but also generates threats for entrepreneurs themselves. For example, cannibalization between channels that can generate confusion and organizational difficulties. 
INTERNATIONAL JOURNAL OF ACADEMIC RESEARCH IN ACCOUNTING, FINANCE AND

MANAGEMENT SCIENCES

Vol. 10, No. 4, 2021, E-ISSN: 2225-8329 @ 2021 HRMARS

Moreover, there is a very important element to be considered, namely the adoption of the omnichannel approach, which involves a reorganization of the company by changing the corporate functions from marketing and transport to distribution and promotion policy etc. (Zhang et al., 2010). In addition to organizational changes, omnichannel retailing requires huge investments in technology and the involvement of qualified personnel in the re-engineering of its business processes (Frazer \& Stiehler, 2014). Thus, there will be always a tendency to integrate the two types of channels, physical and online. Only through this distribution method, it will be possible to reduce the impact on the sales of physical stores in favor of online sales.

In particular, it will be necessary to renew the physical store by implementing innovative in-store technologies that will optimize the physical channel. Finally, the ultimate goal of responding to consumer requests in the best possible way and increasing their level of satisfaction has brought omnichannel retailers to decision of putting the consumer at the center of their attention.

\section{References}

Armstrong, K., \& Rutter, C. (2017). Exploring the enigma of the happiness construct in phygital fashion experiences. Advanced fashion technology and operations management, IGI Global. Hershey, 220-233.

Beck, N., \& Rygl, D. (2015). Categorization of multiple channel retailing in Multi-, Cross-, and OmniChannel Retailing for retailers and retailing. Journal of Retailing and Consumer Services, 27, 170-178.

Bell, D. R., Gallino, S., \& Moreno, A. (2013). Inventory showrooms and customer migration in omnichannel retail: The effect of product information. Available at SSRN, 2370535.

Brynjolfsson, E., Hu Y. J., \& Rahman, M. S. (2013). Competing in the age of omnichannel retailing. MIT Sloan Management Review, 54(4), 23.

Desai, P., Potia, A., \& Salsberg B. (2012). Retail 4.0: The future of retail grocery in a digital world. Asia Consumer and Retail Practice, 1-67.

Fairchild, A. M. (2014). Extending the network: Defining product delivery partnering preferences for omni-channel commerce. Procedia Technology, 16, 447-451.

Falk, T., Schepers, J., Hammerschmidt, M., \& Bauer, H. H. (2007). Identifying cross-channel dissynergies for multichannel service providers. Journal of Service Research, 10(2), 143-160.

Frazer, M., \& Stiehler, B. E. (2014). Omnichannel retailing: The merging of the online and off-line environment. In Global Conference on Business \& Finance Proceedings, Institute for Business \& Finance Research, 9(1), 655.

Granata, G., \& Scozzeze, G. (2018). The Evolution of Virtual Marketing to improve Business Communication. International Business Research, 11 (12).

Granata, G., \& Scozzeze, G. (2019). Social Media Marketing as a tool to manage luxury brands. International Journal of Academic Research in Accounting Finance and Management Sciences, 9 (4).

Grewal, D., Iyer, G. R., \& Levy, M. (2004). Internet retailing: enablers, limiters and market consequences. Journal of Business Research, 57(7), 703-713.

Herhausen, D., Binder, J., Schoegel, M., \& Herrmann, A. (2015). Integrating bricks with clicks: retailerlevel and channel-level outcomes of online-offline channel integration. Journal of Retailing, 91(2), 309-325. 
INTERNATIONAL JOURNAL OF ACADEMIC RESEARCH IN ACCOUNTING, FINANCE AND

MANAGEMENT SCIENCES

Vol. 10, No. 4, 2021, E-ISSN: 2225-8329 @ 2021 HRMARS

Homburg, C., Jozic, D., \& Kuehnl, C. (2017). Customer experience management: toward implementing an evolving marketing concept. Journal of the Academy of Marketing Science, 45(3), 377-401.

Lewis, J., Foster, C., \& Whysall, P. (2013). Understanding the issues associated with going multichannel: preliminary findings from an exploratory study in the UK retail sector. In the 17th EAERCD conference.

Tartaglione, M. A., Granata, G. (2019). Retail Customer Engagement: A Systematic Mapping Study. In Granata G., Moretta Tartaglione A., Tsiakis T., Predicting Trends and Building Strategies for Consumer Engagement in Retail Environments. IGI Global, USA.

Neslin, S. A., Grewal, D., Leghorn, R., Shankar, V., Teerling, M. L., Thomas, J. S., \& Verhoef, P. C. (2006). Challenges and opportunities in multichannel customer management. Journal of Service Research, 9(2), 95-112.

Pentina, I., \& Hasty, R. W. (2009). Effects of multichannel coordination and e-commerce outsourcing on online retail performance. Journal of Marketing Channels, 16(4), 359-374.

Piotrowicz, W., \& Cuthbertson, R. (2014). Introduction to the special issue information technology in retail: Toward omnichannel retailing. International Journal of Electronic Commerce, 18(4), 516.

Rigby, D. (2011). The future of shopping. Harvard Business Review, 89(12), 65-76.

Sawhney, M., \& Kotler, P. (2001). Marketing in the age of information democracy. Kellogg on marketing, 386-408.

Shankar, V., \& Balasubramanian, S. (2009). Mobile marketing: a synthesis and prognosis. Journal of interactive marketing, 23(2), 118-129.

Shankar, V., Venkatesh, A., Hofacker, C., \& Naik, P. (2010). Mobile marketing in the retailing environment: current insights and future research avenues. Journal of interactive marketing, 24(2), 111-120.

Strang, R. (2013). Retail without boundaries. Supply Chain Management Review, 17(6).

Ström, R., Vendel, M., \& Bredican, J. (2014). Mobile marketing: A literature review on its value for consumers and retailers. Journal of Retailing and Consumer Services, 21(6), 1001-1012.

Verhoef, P. C., Kannan, P. K., \& Inman, J. J. (2015). From multi-channel retailing to omni-channel retailing: introduction to the special issue on multi-channel retailing. Journal of retailing, 91(2), 174-181.

Verhoef, P. C., Neslin, S. A., \& Vroomen, B. (2007). Multichannel customer management: Understanding the research-shopper phenomenon. International Journal of Research in Marketing, 24(2), 129-148.

Wallace, D. W., Giese, J. L., \& Johnson, J. L. (2004). Customer retailer loyalty in the context of multiple channel strategies. Journal of retailing, 80(4), 249-263.

Zhang, J., Farris, P. W., Irvin, J. W., Kushwaha, T., Steenburgh, T. J., \& Weitz, B. A. (2010). Crafting integrated multichannel retailing strategies. Journal of Interactive Marketing, 24(2), 168-180. 